\title{
Peculiarities of Culture and In Vitro Contact Interaction of Cryopreserved Thymic Multipotent Stromal Cells and Hemopoietic Cells
}

Реферат: Вивчено особливості поведінки у культурі in vitro кріоконсервованих і свіжовиділених мультипотентних стромальних клітин (МСК) тимуса мишей лінії СВА. Даний тип клітин має певний поверхневий імунофенотип та високу здатність до диференціювання за остео- та адипогенним напрямками у спеціальних середовищах. Після культивування у скляних чашках Петрі, пластикових планшетах і на целофані свіжовиділені та кріоконсервовані клітини показували схожі властивості. При цьому свіжовиділені та кріоконсервовані МСК тимуса на скляній та пластиковій поверхнях фоормували фібробластні колонії, а на целофані спостерігався їх зливний рост. Встановлено, що МСК тимуса мають мембранну спорідненість до тимоцитів, лімфоцитів лімфатичних вузлів і клітин фетальної печінки. Це обумовлює їх здатність до контактної взаємодії 3 різними гемопоетичними клітинами з формуванням асоціацій у вигляді фібробласто-лімфоцитарних розеток (ФЛР). Найбільш ефективна контактна взаємодія (утворення ФЛР) здійснюється за участю МСК і тимоцитів, хоча значну кількість ФЛР утворюють також клітини лімфатичних вузлів і фетальної печінки мишей. Кріоконсервування МСК не впливає на їх здатність до контактної взаємодії, що підтверджує можливість використання кріоконсервування для створення відповідних клітинних трансплантатів.

Ключові слова: кріоконсервування, мультипотентні стромальні клітини, тимус, клітини фетальної печінки, лімфоцити, культури клітин, контактна клітинна взаємодія.

Реферат: Изучены особенности поведения в культуре in vitro криоконсервированных и свежевыделенных мультипотентных стромальных клеток (МСК) тимуса мышей линии СВА. Данный тип клеток имеет определенный поверхностный иммунофенотип и высокую способность к дифференцировки в остео- и адипогенном направлениях в специальных средах. После культивирования в стеклянных чашках Петри, пластиковых планшетах и на целлофане свежевыделенные и криоконсервированные клетки показывали схожие свойства. При этом свежевыделенные и криоконсервированные МСК тимуса на стеклянной и пластиковой поверхностях формировали фрибробластные колонии, а на целлофане наблюдался их сливной рост. Установлено, что МСК тимуса имеют мембранное сродство к тимоцитам, лимфоцитам лимфатических узлов и клеток фетальной печени. Это обусловливает их способность к контактному взаимодействию с различными гемопоэтическими клетками с формированием ассоциаций в виде фрибробласто-лимфоцитарных розеток (ФЛР). Наиболее эффективное контактное взаимодействие (образование ФЛР) осуществляется при участии МСК и тимоцитов, хотя значительное количество ФЛР образуют также клетки лимфатических узлов и фетальной печени мышей. Криоконсервирование МСК не влияет на их способность к контактному взаимодействию, что подтверждает возможность использования криоконсервирования для создания соответствующих клеточных трансплантатов.

Ключевые слова: криоконсервирование, мультипотентные стромальные клетки, тимус, клетки фетальной печени, лимфоциты, культуры клеток, контактное клеточное взаимодействие.

Abstract: The cultural properties of cryopreserved and freshly isolated thymic multipotent stromal cells (MSCs) of CBA mice were investigated. This cell type has certain surface immune phenotype and high ability to differentiation in osteogenic and adipogenic directions in special media. Fresh and cryopreserved cells showed similar properties when cultured in glass petri dishes, plastic plates and cellophane. Both fresh and cryopreserved MSCs of thymus formed fibroblast colonies on glass and plastic surfaces. Cell growth was observed on cellophane. The thymus MSCs were found to have a membrane affinity for thymocytes, lymphocytes of lymph nodes and fetal liver cells. This determined their ability to interact with various hematopoietic cells with the formation of clusters in the form of fibroblast-lymphocytic rosettes (FLR). The most effective contact interaction (FLR formation) occured when the MSCs and thymocytes were involved, nevertheless the cells of mice lymph nodes and fetal liver also formed a significant number of FLRs. MSCs cryopreservation did no affect their ability to the contact interaction, that confirmed the possibility of using the cryopreservation to create appropriate cell transplants.

Key words: cryopreservation, multipotent stromal cells, thymus, fetal liver cells, lymphocytes, cell culture, cell contacts.

ДУ «Інститут генетичної та регенеративної медицини НАМН України», м. Київ
Institute of Genetic and Regenerative Medicine of the National Academy of Medical Sciences of Ukraine, Kyiv, Ukraine
Адреса для кореспонденції:

вул. Вишгородська, 67, м. Київ, Україна 04114;

тел.: (+38 044) 521-33-31

електронна пошта: nakato@bigmir.net

Надійшла 17.07.2017

Прийнята до друку 19.02.2018
Corresponding address:

67, Vyshhorodska str., Kyiv, Ukraine 04114;

tel.:+380445213331

e-mail: nakato@bigmir.net

Received July, 17, 2017

Accepted February, 19, 2018

(c) 2018 K.I. Nikolska. Published by the Institute for Problems of Cryobiology and Cryomedicine

This is an Open Access article distributed under the terms of the Creative Commons Attribution License (http://creativecommons.org/licenses/by/4.0), which permits unrestricted reuse, distribution, and reproduction in any medium, provided the original work is properly cited. 
На сьогодні вивчення властивостей мультипотентних стромальних клітин (МСК) у галузі клітинної терапії є одним із основних напрямків наукових досліджень. Такі клітини отримують із кісткового мозку, тимуса, шкіри, жирової тканини, пуповини, плаценти та інших тканин [13]. Це фібробластоїдні клітини, які адгезують до пластика, мають певний поверхневий імунофенотип і здатні до лінійного диференціювання за остео-, хондро-, адипогенним та іншими напрямками $[11,14,17]$.

У кістковому мозку МСК залучені до структурно-функціональної організації ніш гемопоетичних стовбурових клітин (ГСК) [2, 3]. Тимусні МСК беруть участь у формуванні мікрооточення клітинпопередників у тимусі, суттєво впливають на диференціацію, проліферацію та міграцію тимоцитів. Тимусна мезенхіма відіграє значну роль також в ембріональному розвитку органа [12]. Відомо, що МСК різного походження володіють імуномодулюючою активністю $[10,18]$. Метою чисельних досліджень було вивчення властивостей кістковомозкових МСК. Незважаючи на важливість клітинних процесів у тимусі, властивості тимусних МСК мало досліджені й потребують більш глибокого вивчення. Недостатньо з'ясовані їх культуральні властивості, знання яких має не тільки теоретичне, а й практичне значення для створення клітинних препаратів. У цьому сенсі особлива увага повинна приділятися і дослідженню можливостей кріоконсервування тимусних МСК із збереженням здатності розморожених і культивованих клітин до контактної взаємодії з гемопоетичними клітинами, яка відповідає за функціональну підтримку останніх.

Мета роботи - вивчити особливості розвитку in vitro нативних (некріоконсервованих) і кріоконсервованих МСК тимуса за різних умов культивування і визначити вплив кріоконсервування на здатність МСК тимуса до контактної взаємодії 3 клітинами гемопоетичного ряду.

\section{Матеріали та методи}

Мультипотентні стромальні клітини тимуса мишей лінії СВА культивували на поверхні целофанових пластинок, скляній поверхні культуральних матраців або чашок Петрі та на поверхні лунок пластикових 6-лункових планшетів.

Для культивування застосовували живильне середовище DMEM/F12 («Sigma», CША) з 10\% ембріональної телячої сироватки (ЕTC) («Sigma»), 2,5 мM $L$-глутаміну («Sigma»), 1 MM HEPES («Sigma»), a також по 100 мкг/мл пеніциліну, стрептоміцину та канаміцину («Дарниця», Україна). Перед використанням целофанові пластинки для знежирення поверхні обробляли ефіром і спиртом [4].

Перед культивуванням на целофані тканину тимуса подрібнювали ножицями на шматочки роз-
Nowadays, the study of the properties of multipotent stromal cells (MSCs) is one of the main areas of scientific research in cell therapy. These cells could be derived from bone marrow, thymus, skin, adipose tissue, umbilical cord, placenta and other tissues [8]. These are fibroblastoid cells, which adhere to plastic, have a certain surface immunophenotype and are capable of linear differentiation into the osteo-, chondro-, adipogenic and other directions $[6,11,15]$.

Bone marrow MSCs support the structure and function of niche for hematopoietic stem cells (HSCs) $[9,10]$. Thymic MSCs contribute to formation of the microenvironment for thymus precursor cells, as well as greatly affect the differentiation, proliferation and migration of thymocytes. Thymic mesenchyma plays a significant role in embryonic development of organ too [7]. It is known that MSCs of various origins render an immunomodulatory activity $[10,18]$. The purpose of numerous studies was to investigate the properties of bone marrow MSCs. Due to the importance of processes occurring in thymus cells, the properties of thymic MSCs require a more detailed study. In particular, there is no clear understanding of their properties in culture, that is not only of theoretical but also practical value to create the cell-based medical products. In this regard a special attention should be paid to investigation of the possibility to cryopreserve the thymic MSCs with preserving the ability of frozen-thawed and cultured cells to implement the contact interaction with hematopoietic cells, and in such a way to support the function of the latter.

The research aim was to study the peculiarities of in vitro development of native (i.e. non-cryopreserved) and cryopreserved MSCs of thymus under various culturing conditions and to determine the cryopreservation effect on the ability of thymic MSCs to the contact interactions with hemopoietic cells.

\section{Materials and methods}

Multipotent stromal cells of CBA mice thymus were cultured on a cellophane plates, glass surface of culture flasks or Petri dishes, and in the plastic 6-well plates.

Culture was performed using DMEM/F12 nutrient medium (Sigma, USA) supplemented with $10 \%$ fetal bovine serum (FBS) (Sigma), $2.5 \mathrm{mM} \mathrm{L}$-glutamine (Sigma), $1 \mathrm{mM}$ HEPES (Sigma), $100 \mu \mathrm{g} / \mathrm{ml}$ of Penicillin, Streptomycin and Kanamycin (Darnitsa, Ukraine). Before using the cellophane plates were ungreased by ether and alcohol [12].

Prior to culturing on cellophane plate, the thymus tissue was cut with scissors to obtain the fragments less than $1 \mathrm{~mm}^{3}$, then they were fixed in dissected cellophane plates $\left(1 \mathrm{~cm}^{2}\right)$ and placed into penicillin vials with culture medium $(5 \mathrm{ml})$. The vials with the samples were kept in a thermostat at $37^{\circ} \mathrm{C}$. Every 5 days the culture medium was changed. 
міром не більше 1 мм³, фрагменти фіксували у розрізах целофанових пластинок (1 c $\left.\mathrm{cm}^{2}\right)$, які поміщали у пеніцилінові флакони з культуральним середовищем (5 мл). Флакони 3 матеріалом витримували у термостаті при температурі $37^{\circ} \mathrm{C}$. Через кожні 5 діб середовище культивування замінювали.

Перед культивуванням клітин на скляній або пластиковій поверхнях тканину тимуса подрібнювали на шматочки розміром не більше 1 мм³ $^{3}$ При цьому велика кількість тимоцитів, що не адгезують до поверхні, переходила в середовище. Фрагменти тканини двічі промивали розчином Хенкса, відмивали від тимоцитів і потім переносили у судини для культивування. До скляного культурального матрацу (50 см²) або до чашки Петрі (діаметр $10 \mathrm{~cm}$ ) переносили фрагменти цілого тимуса, до ячейки 6-лункового пластикового планшета - фрагменти половини органа в мінімальному об'ємі живильного середовища, щоб поверхня дна матрацу, чашки або лунки була трохи змоченою. Культури переносили в $\mathrm{CO}_{2}$-інкубатор («Jouan», Франція) з 5\% $\mathrm{CO}_{2}$ при $37^{\circ} \mathrm{C}$. Через 2 години, коли шматочки тимуса вже прикріпилися до поверхні, додавали живильне середовище. Через кожні 3-4 доби половину середовища замінювали на свіже. За виходом клітин із експлантатів та їх ростом спостерігали у світловому інвертованому мікроскопі, фіксуючи активність клітинного росту на всіх термінах спостереження. Прикріплені експлантати видаляли із культури через 7-10 діб механічним шляхом. У кожному експерименті вивчали по 5-6 культур. Через 1530 діб клітини тимуса, які культивувалися на целофанових пластинках, та колонії, що сформувалися на пластиковій або скляній поверхнях, фіксували розчином Май-Грюнвальда та забарвлювали азурIIеозином.

3 метою ідентифікування МСК вивчали їх здатність до диференціювання за остео- та адипогенним напрямками. Остеогенне диференціювання клітин індукували культивуванням у середовищі DMEM/F12, 1:1 із додаванням 15\% ETC; 10 мM $L$ глютаміну; 50 мкг/мл $L$-аскорбінової кислоти; 10 мМ $L$-гліцерофосфату; 0,1 мкМ дексаметазону (все від «Sigma») та по 100 мкг/мл пеніциліну і стрептоміцину («Дарниця», Україна). Адипогенне диференціювання клітин індукували культивуванням у середовищі DMEM-HG («PAA», Німеччина) з високим вмістом глюкози (4,5 г/л) і додаванням 10\% конячої сироватки («РАA»); 10 мМ L-глютаміну («Sigma»); 0,5 мкМ дексаметазону («Sigma»), 6 мкг/мл інсуліну («Sigma») та по 100 мкг/мл пеніциліну і стрептоміцину («Дарниця»). Культивування проводили в $\mathrm{CO}_{2}$-інкубаторі («Jouan») при $37^{\circ} \mathrm{C}$ i 5\% $\mathrm{CO}_{2}$ протягом 10 діб.

Ефективність диференціювання клітин визначали фарбуванням індукованих в остеогенному
Before cell culturing on glass or plastic surfaces, the thymus tissue was fragmented to pieces less than $1 \mathrm{~mm}^{3}$. Thereat a large number of thymocytes was released into the medium. Tissue fragments were washed twice with Hanks solution, washed free of thymocytes and then transferred to culturing vials. The fragments of the whole thymus were transferred either into a glass culture flask $\left(50 \mathrm{~cm}^{2}\right)$ or a Petri dish $(10 \mathrm{~cm}$ diameter). The fragments of a half of the organ in the nutrient medium were placed into the cell of 6-well plastic plate, the amount of the medium was enough to slightly moisten the culture surface of the flask, plate or well. The specimens were transferred into $\mathrm{CO}_{2}$ incubator (Jouan, France) with $5 \% \mathrm{CO}_{2}$ at $37^{\circ} \mathrm{C}$. After 2 hours the fragments of thymus were attached to the surface and a nutrient medium was introduced. Every 3-4 days a half of the medium was replaced with a fresh one. The migration of cells from the explants and their growth were observed using an inverted light microscope, the activity of cell growth was recorded within all the observation terms. The attached explants were mechanically removed from the culture after $7-$ 10 days. In each experiment, 5-6 cultures were studied. After 15-30 days the thymus cells cultured on cellophane plates and the colonies formed on plastic or glass surfaces were fixed with May-Grunwald solution and stained by AzureII-Eosin.

To identify the MSCs, their ability to differentiate in osteo- and adipogenic directions was studied. Osteogenic cell differentiation was induced by culturing in DMEM/F12 medium, 1:1 with addition of $15 \%$ ETC; $10 \mathrm{mM} L$-glutamine (Sigma); $50 \mu \mathrm{g} / \mathrm{ml}$ of $L$-ascorbic acid; $10 \mathrm{mM}$ L-glycerophosphate; $0.1 \mathrm{mM}$ dexamethasone (all from Sigma) and $100 \mu \mathrm{g} / \mathrm{ml}$ of Penicillin and Streptomycin (Darnitsa, Ukraine). Adipogenic cell differentiation was induced by culturing in DMEM-HG medium (PAA, Germany) with a high glucose content $(4.5 \mathrm{~g} / \mathrm{L})$ and addition of $10 \%$ horse serum (PAA); $10 \mathrm{mM} L$-glutamine; $0.5 \mathrm{mM}$ dexamethasone, $6 \mu \mathrm{g} / \mathrm{ml}$ insulin (all from Sigma) and $100 \mu \mathrm{g} / \mathrm{ml}$ Penicillin and Streptomycin (Darnitsa). Culturing was performed in a $\mathrm{CO}_{2}$-incubator (Jouan) at $37^{\circ} \mathrm{C}$ and $5 \% \mathrm{CO}_{2}$ for 10 days.

The efficiency of cell differentiation was determined by staining the calcium salts deposits in the cultures induced in osteogenic direction using 1\% Alizarin Red S, and the cells developing in adipogenic direction were treated with $0.2 \%$ Oil Red O (both dyes from Sigma) to reveal lipid vacuoles [13]. Alizarin Red and Oil Red were extracted with $10 \%$ acetic acid or isopropyl alcohol, respectively. Optical density of obtained solutions was assessed in 96-well plate containing $200 \mu$ l of extract with spectrophotometer Sunrise (Tecan, Austria) at a wavelength of $520 \mathrm{~nm}$.

Considering the fact that the experimental study of cell sensitivity to cryopreservation requires quite a large number of standardized cells, some of the second 
напрямку культур на відкладення солей кальцію $1 \%$-м розчином алізаринового червоного S («Sigma») та індукованих в адипогенному напрямку культур на ліпідні вакуолі 0,2\%-м розчином масляного червоного O («Sigma») [15]. Алізариновий червоний та масляний червоний екстрагували 10\%-м розчином оцтової кислоти або ізопропіловим спиртом відповідно. Інтенсивність забарвлення отриманих розчинів оцінювали в ячейках 96-лункового планшета, які містили по 200 мкл екстракту, вимірюючи оптичну густину на спектрофотометрі «Sunrise» («Тесап», Австрія) при довжині хвилі 520 нм.

Враховуючи, що для постановки експериментів і вивчення чутливості клітин до кріоконсервування потрібна достатня кількість клітин із бажано більш стандартизованими властивостями, ми отримували пул МСК 2-го пасажу, накопичували і зберігали кріоконсервуванням, використовуючи програмний заморожувач «KRYO 560 16» («Planen», Велика Британія) і ДМСО в кінцевій концентрації 5\%. Клітини заморожували в три етапи: перший етап - від кімнатної температури до $(-3,5 \pm 0,5)^{\circ} \mathrm{C}$ зі швидкістю охолодження $(1 \pm 0,5)$ град/хв; другий етап швидкість охолодження $(0,4 \pm 0,1)$ град/хв до температури $-9^{\circ} \mathrm{C}$; третій етап - до температури $80^{\circ} \mathrm{C}$ зі швидкістю охолодження 10 град/хв. Потім пробірки $з$ клітинами занурювали у рідкий азот. Зразки розморожували безпосередньо перед застосуванням при температурі $(40 \pm 0,5)^{\circ} \mathrm{C}$ до появи в кріопробірці рідкої фази. Після повного розморожування клітини відмивали від кріопротектора шляхом центрифугування при $250 \mathrm{~g}$ протягом 5 хв i3 подальшим ресуспендуванням у живильному середовищі.

Тимоцити і клітини лімфатичних вузлів дорослих мишей та клітини фетальної печінки 14-денних ембріонів мишей линії СВА отримували диспергуванням органів в середовищі препарувальними голками, фільтрацією суспензії через нейлонове сито і відмиванням у такому ж середовищі.

Постановку реакції утворення фібробластолімфоцитарних розеток (ФЛР) здійснювали наступним чином, при цьому за розетку вважали асоціацію MCK із трьома і більше лімфоцитами. У мікропробірку вносили $1 \times 10^{4} \mathrm{MCK}$ у 0,1 мл живильного середовища. Потім в 0,1 мл середовища додавали $1 \times 10^{6}$ тимоцитів, клітин лімфатичних вузлів або фетальної печінки (1:100). Перемішану суспензію клітин центрифугували при $250 \mathrm{~g}$ протягом 5 хв. Осад негайно ресуспендували піпетуванням в об'ємі 0,1 мл. Для забарвлювання МСК краплю суспензії наносили на покрите нейтральним червоним предметне скло. Потім суспензію переносили в камеру Горяєва, в якій підраховували кількість ФЛР. Кожну пробу дублювали і обчислювали середнє значення. Результати виражали в процентах. passage cells were frozen with controlled rate freezer KRYO-560 16 (Planer, UK) using DMSO in a final concentration of $5 \%$. The cells were frozen by three step procedure: the first step was the freezing from room temperature down to $(-3.5 \pm 0.5){ }^{\circ} \mathrm{C}$ with a cooling rate of $(1 \pm 0.5) \mathrm{deg} / \mathrm{min}$; the second step involved the cooling rate $(0.4 \pm 0.1) \mathrm{deg} / \mathrm{min}$ down to $-9^{\circ} \mathrm{C}$; the third stage comprised freezing down to $80^{\circ} \mathrm{C}$ with a cooling rate of $10 \mathrm{deg} / \mathrm{min}$. After that, the tubes with cells were immersed into liquid nitrogen. The samples were thawed immediately prior to further use at a temperature of $(40 \pm 0.5)^{\circ} \mathrm{C}$ up to the liquid phase appearance in the cryovial. After complete thawing, the cells were washed from cryoprotectant using centrifugation at $250 \mathrm{~g}$ for $5 \mathrm{~min}$ and following resuspending in the nutrient medium.

Thymocytes and cells of lymph nodes of adult mice and fetal liver cells of 14-day-old CBA mice embryos were obtained by means of dispersing the organs in the medium with preparation needles, filtration of the suspension through nylon sieve and washing in the similar medium.

The assessment of fibroblast-lymphocyte rosettes (FLRs) formation was performed as follows. Herewith cluster of MSCs with three or more lymphocytes was considered as a rosette. Microtube was filled with 0.1 $\mathrm{ml}$ of nutrient medium and $1 \times 10^{4} \mathrm{MSC}$ s was added. Then $1 \times 10^{6}$ thymocytes, cells of lymph nodes or fetal liver $(1: 100)$ were added to $0.1 \mathrm{ml}$ of the medium. The suspension of cells was stirred and centrifuged at $250 \mathrm{~g}$ for $5 \mathrm{~min}$. The sediment was immediately resuspended by pipetting in a $0.1 \mathrm{ml}$ volume. To stain the MSCs, a drop of suspension was put to a glass slide coated with Neutral Red. Thereafter suspen-sion was transferred to Goryaev's counting chamber, and the number of FLRs was calculated. Each sample was duplicated and a mean value was calculated. The results were expressed as a percentage.

The results were statistically processed according to Chauvenet's criteria (to identify abnormal results of measurements), Student $(t)$ and non-parametric Wilcoxon-Mann-Whitney $(U)$ criterion (to determine the significance of differences).

\section{Results and discussion}

Results of culturing of thymus MSCs under different conditions. Culturing on cellophane plates in the first two days resulted in adaptation of the explants to new culturing conditions, herewith they looked like dense fragments. Noticeable start of the cell proliferation and their migration from the explants were observed for 3-4 days. The fibroblastoid cells began to migrate beyond the explants and adhered on the surface of the cellophane plate. Thereafter their active propagation began: the number of cells was increased on both surfaces of the foil and in some cases 
Статистичну обробку результатів проводили за критеріями Шовене (для виявлення аномальних результатів вимірювань), Стьюдента $(t)$ та непараметричним критерієм Вілкоксона-Манна-Уїтні $(U)$ (для визначення значущості відмінностей).

\section{Результати та обговорення}

Результати культивування МСК тимуса в piзних умовах. Під час культивування на целофанових пластинках у перші дві доби експлантати адаптувалися до нових умов культивування, при цьому вони мали вигляд щільних шматочків. Помітний початок розмноження клітин та їх вихід із експлантатів відмічалися на 3-4 добу. Фібробластоїдні клітини починали мігрувати за межі експлантатів і адгезували в зоні контакту з поверхнею целофанової плівки. Надалі розпочиналося їх активне розмноження: кількість клітин збільшувалася на обох поверхнях плівки, а в деяких випадках вони займали всю їі площу. Найбільше зосередження клітин спостерігалося в зонах, наближених до експлантатів, поступово їх кількість зменшувалася пропорційно віддаленості від експлантата. Щільність фібробластоїдних клітин у зоні росту була неоднакова: клітини, що наближені до експлантата, тісно контактували між собою, мали менший розмір, із збільшенням відстані від експлантата до краю пласта їх розміри збільшувалися, між ними 3'являлися щілини та різної величини порожнини. Найбільш активна проліферація цих клітин відмічалася на 12-13-ту добу культивування і суттєво зменшувалася до 30-ї доби.

Під час культивування на скляній або пластиковій поверхні в перші 2-3 доби навколо фрагментів тимуса густим шаром лежали тимоцити, які виходили із цих фрагментів. Вони не прикріплялися до поверхні, і тому кількість тимоцитів зменшувалася 3 кожною заміною середовища, на 10-12-ту добу культивування вони практично повністю зникали.

На 3-4 добу культивування серед дрібних округлих тимоцитів виявлялися окремі більші за розмірами клітини, які, на відміну від тимоцитів, прикріплялися до поверхні. На 5-6-ту добу на цьому місці формувалися кластери і колонії великих овальних клітин, які у подальшому мали вигляд блідої білої плями. У складі колоній поступово з'являлися менші за розміром клітини типового фібробластоподібного типу, при цьому їх кількість збільшувалася. Великі овальні клітини, які, можливо, повільно реагують на контакт із поверхнею і затримують звичайне формування виростів, залишалися у складі сформованих колоній, але їх кількість була значно меншою (1:20 -1:40). В окремих експериментах кількість колоній складала від 2-3 до 50 на культуральну поверхню. Ця розбіжність у кількості утворених колоній фібробластів, можливо, відображає they occupied the entire area. The highest concentration of cells was observed in the zones close to the explants, their number decreased gradually directly depending on the distance from the explant. The density of fibroblastoid cells in the growth zone was not equal: the cells being close to the explant had the mutual contacts, were of a smaller size; the bigger was the distance from the explant to the plate edge the larger were the cells; there were appeared the gaps and cavities of different sizes between the cells. The most active proliferation of these cells was observed to days $12-13$ of culturing and significantly decreased to the day 30 .

Culturing either on a glass or plastic surface resulted in the migration of vast amount of thymocytes from thymus fragments in the first 2-3 days. They were not attached to the surface, and therefore the number of thymocytes decreased with each replacement of the medium, they disappeared almost completely to the $10-12^{\text {th }}$ day of culturing.

To the $3-4^{\text {th }}$ days of culturing among small rounded thymocytes the single larger cells appeared, which attached to the surface unlike thymocytes. To the 5$6^{\text {th }}$ day, the clusters and colonies of large oval cells were formed, and later appeared as pale white spots. The colonies which included smaller cells of fibroblast like type appeared, their number increased gradually. Large oval cells, which likely slowly respond to contact with the surface and inhibit the normal formation of the processes, remained in the formed colonies, but their number was significantly lower $(1: 20-1: 40)$. In some experiments, the number of colonies was from 2-3 up to 50 per culture surface. This diversity in the number of the formed fibroblast colonies may reflect the differences of growth conditions in certain culture plates or individual properties of MSCs of various tissue samples [3].

The stained cell colonies on the surface of glass flask, glass surface of Petri dish, as well as in the cells of the plastic 6-well plate were easy to observe (Fig. 1).

Analysis of the colonies of thymic MSCs with microscope revealed the cells of fibroblastoid morphology, with different size and distribution in the area (Fig. 2). In the cultures on cellophane plates the cells were 'crowding' without formation of colonies. This likely testified to a strong effect of culture surface characteristics on the features of cell culture development.

Thus, culturing of the CBA mice thymus fragments on glass and plastic surfaces resulted in the almost the same dynamics of culture development and formation of the colonies containing different morphological types of adhesive fibroblastoid cells. Culturing of the cells on cellophane surface was accompanied with cell crowding.

In the following experiments we have used the cryopreserved thymic MSCs of the second passage with 

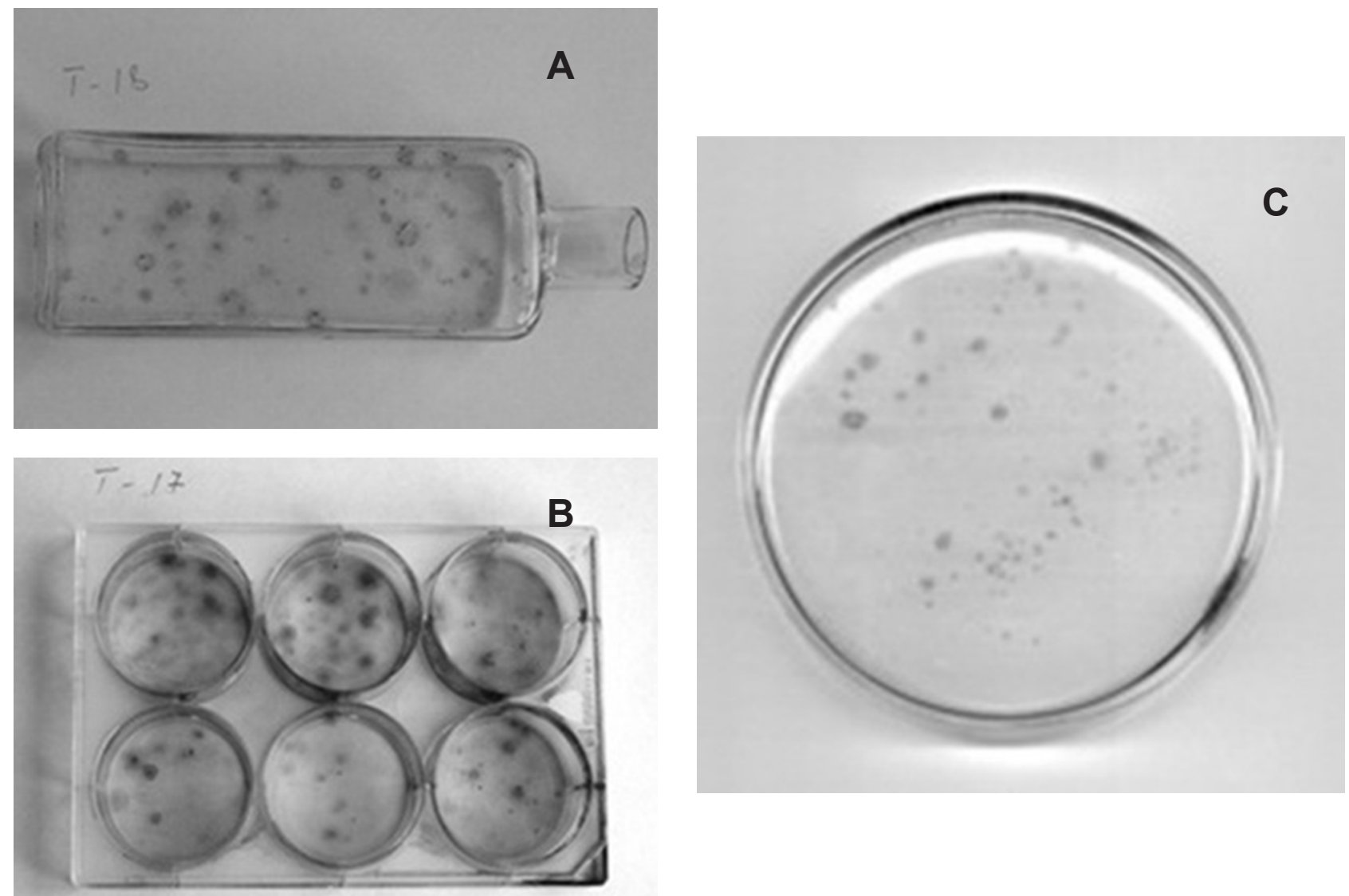

Рис. 1. Утворення колоній МСК тимуса мишей лінії СВА на поверхні скляного матрацу (А), пластикового 6-лункового планшета (B), скляної чашки Петрі (C) через 15 діб культивувння. Забарвлювання азур II-еозином.

Fig. 1. Formation of colonies of CBA murine thymic MSCs on surface of glass culture flask (A), plastic 6-well plate (B), Petri dish (C) after 15 days of culturing. Stained with Azure II-Eosin.

відмінності умов нарощування у певних культуральних посудинах або індивідуальні властивості МСК із різних зразків тканини [7].

Забарвлені колонії клітин на поверхні скляного матраца, скляній поверхні чашки Петрі, а також у комірках пластикового 6-лункового планшета було видно неозброєним оком (рис. 1).

Мікроскопічний аналіз встановив, що в колоніях МСК тимуса клітини мають різну фібробластоподібну морфологічну структуру, розмір та характер розподілу по площі (рис. 2). У культурах на целофанових пластинках для клітин характерні ознаки зливного росту без формування колоній. Можливо, це свідчить про суттєвий вплив культуральної поверхні на характер розвитку клітинної культури.

Таким чином, у процесі культивування фрагментів тимуса мишей лінії СВА на скляній та пластиковій поверхнях отримано схожі результати з практично однаковою динамікою розвитку культур та утворенням колоній, які містять різні морфологічні типи адгезуючих фібробластоїдних клітин. Під час культивування клітин на поверхні целофанових пластинок спостерігався їх зливний ріст.
$82-86 \%$ viability. The dynamics and peculiarities of growth, as well as their ability to colony formation after thawing corresponded to the norm.

Fibroblastolymphocytic clusters. Taking into account the data on the membrane interaction of MSCs and hematopoietic cells, we have examined if this process is possible in vitro at a short-term contact. The frozen-thawed thymic MSCs were suspended, washed and used to react with thymocytes, lymph nodes, or fetal liver cells.

The suspension contained the formed groups with centrally located MSCs and hemopoietic cells around, i. e. FLRs (Fig. 3). A relative number of MSCs that formed FLRs was counted.

Non-frozen and cryopreserved thymic MSCs formed a high number of FLRs with thymocytes (Table). Significantly lower number of FLRs was formed by the cells of the lymph nodes and fetal liver, that generally corresponded to the published data on a higher affinity to MSCs of immature T-lymphocytes [9]. It is also known that mature lymphocytes have a membrane affinity to $\mathrm{MSCs}[8,16]$, which is the feature of fetal liver precursor cells as well $[2,3]$. It is impor- 

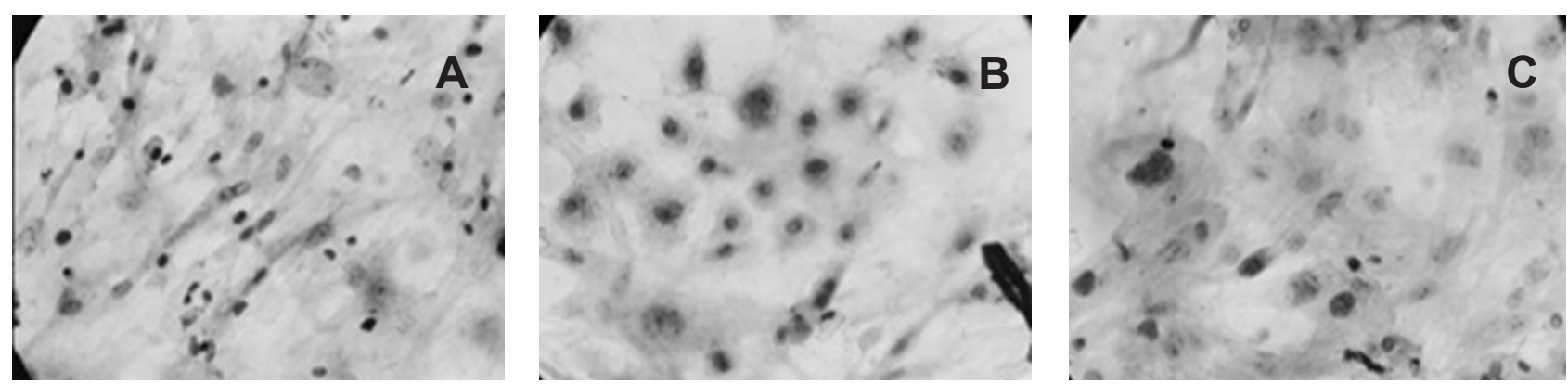

Рис. 2. Культури МСК тимуса мишей лінії СВА на целофані (A), пластиковій (В) та скляній (C) поверхнях. Забарвлювання азур II-еозином, ×200.

Fig. 2. Cultures of CBA murine thymic MSCs on cellophane (A), plastic (B) and glass surfaces (C). Stained with Azure II-Eosin, $\times 200$.

Отримані у зазначених умовах МСК тимуса ефективно диференціювалися у спеціальних середовищах за остео- та адипогеним напрямками. Показник їх життєздатності за ексклюзією трипанового синього становив 82-86\%. Динаміка і особливості росту клітин, а також їх здатність до колонієутворення після розморожування відповідали нормі.

Фібробластолімфоиитарні асоиіаиії. Враховуючи дані щодо мембранної взаємодії МСК і гемопоетичних клітин, ми визначили можливість реалізації цього процесу в умовах in vitro при короткочасному їх контакті. Деконсервовані МСК тимуса суспендували, відмивали і використовували для реакції з тимоцитами, клітинами лімфатичних вузлів або фетальної печінки

У суспензії утворювалися асоціації з центрально розташованої МСК і приєднаних до неї гемопоетичних клітин, тобто ФЛР (рис. 3). Підраховували відносну кількість МСК, які формували ФЛР.

Встановлено, що нативні та кріоконсервовані МСК тимуса утворювали велику кількість ФЛР із тимоцитами (таблиця). Значно меншу кількість ФЛР утворювали клітини лімфатичних вузлів і фетальної печінки, що в цілому відповідає літературним даним про більш високу спорідненість до МСК незрілих Т-лімфоцитів [8]. Крім того відомо, що і зрілі лімфоцити мають мембранну спорідненість до МСК $[9,16]$, яка притаманна клітинампопередникам фетальної печінки [2, 3]. Однак важливим $€$ той факт, що у нефракціонованій суспензії останніх присутня велика кількість еритроцитів, а це може заважати утворенню ФЛР клітинами фетальної печінки лімфоїдного і мієлоїдного ряду.

Таким чином, встановлено, що в результаті короткочасного контакту МСК тимуса з лімфоцитами і клітинами фетальної печінки в суспензії in vitro формуються їх асоціації у вигляді ФЛР. Більш виражена здатність до контактної взаємодії з МСК тимуса притаманна тимоцитам, що, можливо, свідчить tant to note that the unfractionated suspension of these cells contain a large amount of erythrocytes. This may complicate the formation of FLRs by fetal liver cells of lymphoid and myeloid series.

Thus, it was established that a short-term contact of thymic MSCs with lymphocytes and fetal liver cell suspension in vitro, resulted in their grouping in the form of FLRs. A more pronounced ability to the contact interaction with thymic MSCs was inherent to thymocytes, that might indicate the importance of membrane affinity of the studied cells in thymus functioning and in the thymic niches of stem cells. The activity of the CBA mice thymic MSCs in forming the FLRs had not been changed after cryopreservation (Table). This testifies to the resistance to cryoeffect of the cellto-cell contact interaction function in MSCs. The ability of cryopreserved MSCs to form the colonies also did not change significantly. The previous results of the experiments in human fetal MSCs had shown that

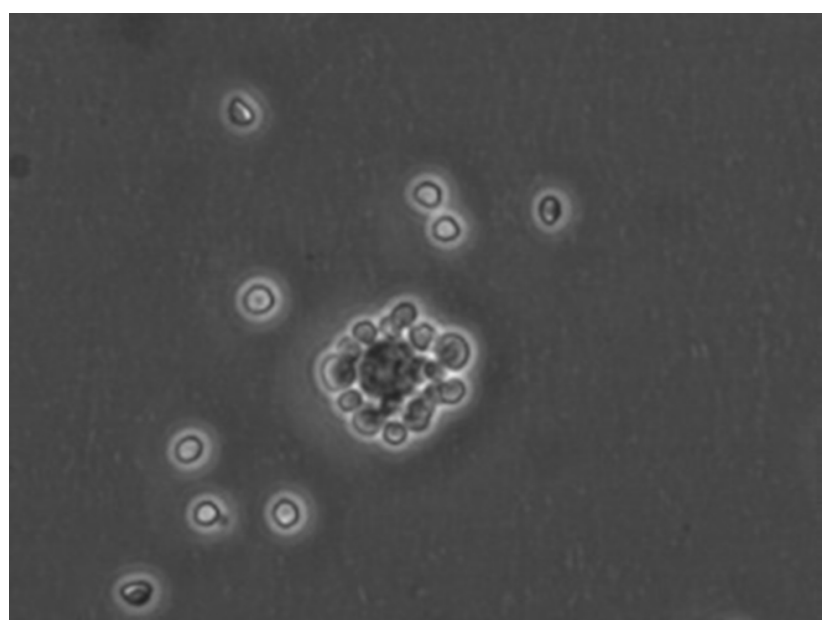

Рис. 3. Фібробластолімфоцитарні розетки, утворені МСК тимуса та тимоцитами мишей лінії СВА. Фазовий контраст, $\times 320$.

Fig. 3. Fibroblast-lymphocyte rosettes, formed by thymic MSCs and thymocytes of CBA mice, $\times 320$. Phase contrast. 
про важливість мембранної спорідненості вивчених клітин у функціонуванні тимуса та в тимусних нішах стовбурових клітин. Активність МСК тимуса мишей лінії СВА при формуванні ФЛР у результаті кріоконсервування не змінилася (таблиця). Це свідчить про стійкість до кріовпливу контактної міжклітинної взаємодії у МСК. Здатність кріоконсервованих МСК до колонієутворення теж суттєво не змінилася. Результати експериментів на фетальних МСК людини довели, що кріоконсервування МСК, зокрема під захистом ДМСО, впливає на їх здатність до диференціювання $[1,5$, 6]. Ці розбіжності кріоконсервування по відношенню до двох видів функціональної активності МСК (здатності до мембранної взаємодії та колонієутворення) важко співставити з огляду на різне видове та тканинне походження МСК, використаних у роботі, та клітин, досліджених у приведених вище джерелах. Ймовірно також, що різні прояви функціональної активності МСК (здатність до контактної міжклітинної взаємодії та колонієутворення) опосередковані окремими механізмами, що відрізняються за чутливістю до кріоконсервування.

\section{Висновки}

1. Показано, що свіжовиділені та кріоконсервовані МСК тимуса мишей лінії СВА, які здатні до диференціювання за остео- і адипогенним напрямками, можна однаково ефективно культивувати на скляній і пластиковій поверхнях, чашках Петрі та лунках планшетів (утворення колоній), а також на целофанових пластинах (формування моношару 3 обох сторін целофану). Нарощені та кріоконсервовані МСК тимуса другого пасажу мають виживаність 80-90\%. Методи нарощування МСК тимуса in vitro та накопичення необхідної їх кількості шляхом кріоконсервування можуть бути перспективними для використання у клінічній практиці.

2. Встановлено, що змішування суспензій свіжовиділених і розморожених МСК тимуса 3 тимоцитами або клітинами лімфатичних вузлів та фетальної печінки мишей із наступним центрифугуванням та ресуспендуванням сприяє формуванню асоціацій МСК і названих гемопоетичних клітин у вигляді ФЛР. Це свідчить про наявність у цих клітин мембранної спорідненості та про іiі збереження у взаємодіючих клітин після кріоконсервування. Найбільшою здатністю до контактної взаємодії з МСК тимуса володіють тимоцити.

3. Одержані результати дозволяють рекомендувати розроблений експериментальний підхід для cryopreservation of MSCs, in particular under the protection of DMSO, affected their ability to differentiate $[1,5,6]$. These differences as for cryopreservation in two types of functional activity of MSCs: the ability to membrane interaction, on the one hand, and colony formation on another, could be hardly compared due to different species and tissue, which were the sources of MSCs used in our work and studied in the researches mentioned above. It is also likely that various manifestations of functional activity of MSCs such as the ability to the cell-to-cell contact interaction and colony formation, are mediated by certain mechanisms, varying in cryopreservation sensitivity.

\section{Conclusions}

1. It has been shown that freshly isolated and cryopreserved CBA mice thymic MSCs, capable to differentiate by osteo- and adipogenic directions, can be equally efficiently cultured on a glass and plastic surface, Petri dishes and plate wells (in terms of colonies formation), as well as on cellophane plates (formation of a monolayer on both sides of cellophane). Grown and cryopreserved thymic MSCs of the second passage had a survival rate of $80-90 \%$. The methods of growing of thymic MSCs in vitro and reaching their required number are promising to be used in clinical practice.

2. It was found that mixing the suspensions of freshly isolated and frozen-thawed thymic MSCs with thymocytes or cells of lymph nodes and murine fetal liver followed by centrifugation and re-suspending resulted in the grouping of MSCs and hematopoietic cells in the form of FLRs. This testifies to the presence of membrane affinity in these cells and its preservation in interacting cells after cryopreservation. The thymocytes possessed the highest ability to the contact interaction with thymic MSCs. 
вивчення механізмів міжклітинної взаємодії з метою подальшого використання у кріобіології.

\section{Література}

1. Грищенко В.И., Петренко А.Ю., Волкова Н.А., Скоробогатова Н.Г. Колониеобразующая активность фрибробластоподобных клеток-предшественников из эмбриональной печени человека в условиях in vitro. Доповіді НАН України 2005; 2: 128-141.

2. Никольская Е.И. Клеточная композиция костномозговых ниш гемопоэтических стволовых клеток. Журнал НАМН України 2015; 21(3-4): 272-286.

3. Никольская Е.И., Бутенко Г.М. Структурно-фрункциональная организация костномозговых ниш гемопоэтических стволовых клеток. Клітинна та органна трансплантологія 2016 4(1): 82-100.

4. Пол Д. Культура клеток и тканей. Москва: Медицина; 1963.

5. Скоробогатова Н.Г., Волкова Н.А., Петренко А.Ю. Остеогенные и адипогенные свойства фибробластоподобных клеток-предшественников фетальной печени человека. Цитология 2008; 4: 317-322.

6. Тарасов А.И., Петренко А.Ю., Грищенко В.И., Джонс Д.Р.Е. Жизнеспособность клеток эмбриональной печени человека различного фенотипа после криоконсервирования Проблемы криобиологии 2002; 3: 36-41.

7. Чертков И.Л., Гуревич О.А. Стволовая кроветворная клетка и ее микроокружение. Москва: Медицина; 1984.

8. Anderson G., Anderson K.L., Tchilian E.Z. et al. Fibroblast dependency during early thymocyte development maps to the $\mathrm{CD} 25^{+} \mathrm{CD} 44^{+}$stage and involves interactions with fibroblast matrix molecules. Eur J Immunol 1997; 27(5): 1200-1206.

9. Anderson G., Moore N.C., Owen J.J., Jenkinson E.J. Cellular interactions in thymocyte development. Annu Rev Immunol 1996; 14: 73-99.

10.Kassis I., Vaknin-Dembinsky A., Karussis D. Bone marrow mesenchymal stem cells: agents of immunomodulation and neuroprotection. Curr Stem Cell Res Ther 2011; 6(1): 63-68.

11.Le Blanc K., Mougiakakos D. Multipotent mesenchymal stromal cells and the innate immune system. Nat Rev Immunol 2012; 12(5): 383-396

12.Mouiseddine M., Mathieu N., Stefani J. et al. Characterization and histological localization of multipotent mesenchymal stromal cells in the human postnatal thymus. Stem Cells Dev 2008 17(6); 1165-1174.

13.Musina R.A., Bekchanova E.S., Sukhikh G.T. Comparison of mesenchymal stem cells obtained from different human tissues. Bull Exp Biol Med 2005; 139(4): 504-509.

14.Osada M., Singh V.J., Wu K. et al. Label retention identifies a multipotent mesenchymal stem cell-like population in the postnatal thymus. PLoS One 2013; 8(12): e83024.

15.Prockop D.J., Phinney D.G., Bunnell B.A. Mesenchymal stem cells: methods and protocols. Totowa, NJ: Humana Press; 2008.

16.Sawada M., Nagamine J., Takeda K. et al. Expression of VLA-4 on thymocytes. Maturation stage-associated transition and its correlation with their capacity to adhere to thymic stromal cells. J Immunol 1992; 149(11): 3517-3524.

17.Siepe M., Thomsen A.R., Duerkopp N. et al. Human neonatal thymus-derived mesenchymal stromal cells: characterization, differentiation, and immunomodulatory properties. Tissue Eng Part A 2009; 15(7): 1787-1796.

18.Spaggiari G.M., L. Moretta. Cellular and molecular interactions of mesenchymal stem cells in innate immunity. Immunol Cell Biol 2013; 91(1): 27-31.
3. The findings allow to recommend the developed experimental approach for studying the mechanisms of cell-to-cell interaction and its application in cryobiological studies.

\section{References}

1. Anderson G., Anderson K.L., Tchilian E.Z. et al. Fibroblast dependency during early thymocyte development maps to the $\mathrm{CD} 25^{+} \mathrm{CD} 44^{+}$stage and involves interactions with fibroblast matrix molecules. Eur J Immunol 1997; 27(5): 1200-1206.

2. Anderson G., Moore N.C., Owen J.J., Jenkinson E.J. Cellular interactions in thymocyte development. Annu Rev Immunol 1996; 14: 73-99.

3. Chertkov I.L., Gurevich O.A. Stem hematopoietic cell and its microenvironment. Moscow: Meditsyna; 1984.

4. Grischenko V.I., Petrenko A.Yu., Volkova N.A., Skorobogatova N.G. Colony-forming activity of fibroblast-like precursor cells from human embryonic liver under in vitro conditions. Dopov Nac Akad Nauk Ukr 2005; 2: 128-141.

5. Kassis I., Vaknin-Dembinsky A., Karussis D. Bone marrow mesenchymal stem cells: agents of immunomodulation and neuroprotection. Curr Stem Cell Res Ther 2011; 6(1): 63-68.

6. Le Blanc K., Mougiakakos D. Multipotent mesenchymal stromal cells and the innate immune system. Nat Rev Immunol 2012; 12(5): 383-396.

7. Mouiseddine M., Mathieu N., Stefani J. et al. Characterization and histological localization of multipotent mesenchymal stromal cells in the human postnatal thymus. Stem Cells Dev 2008; 17(6); $1165-1174$

8. Musina R.A., Bekchanova E.S., Sukhikh G.T. Comparison of mesenchymal stem cells obtained from different human tissues. Bull Exp Biol Med 2005; 139(4): 504-509.

9. Nikolskaya E. I., Butenko G. M. Structural-functional organisation of the bone marrow hematopoietic stem cells niches. Cell and Organ Transplantology 2016; 4(1): 82-100.

10.Nikolskaya E.I. The cellular composition of bone marrow of hematopoietic stem cells niches. Zhurnal Natsionalnoi Akademii Medychnykh Nauk Ukrainy 2015; 21(3-4): 272-286.

11.Osada M., Singh V.J., Wu K. et al. Label retention identifies a multipotent mesenchymal stem cell-like population in the postnatal thymus. PLoS One 2013; 8(12): e83024.

12.Pol D. Culture of cells and tissues. Moscow: Meditsyna; 1963.

13.Prockop D.J., Phinney D.G., Bunnell B.A. Mesenchymal stem cells: methods and protocols. Totowa, NJ: Humana Press; 2008.

14.Sawada M., Nagamine J., Takeda K. et al. Expression of VLA-4 on thymocytes. Maturation stage-associated transition and its correlation with their capacity to adhere to thymic stromal cells. J Immunol 1992; 149(11): 3517-3524.

15.Siepe M., Thomsen A.R., Duerkopp N. et al. Human neonatal thymus-derived mesenchymal stromal cells: characterization, differentiation, and immunomodulatory properties. Tissue Eng Part A 2009; 15(7): 1787-1796.

16.Skorobogatova N.G., Volkova N.A., Petrenko A.Yu. Osteogenic and adipogenic capacity of fibroblast-like progenitor cells derived frow human fetal liver. Tsitologiya 2008; 4: 317-322.

17.Spaggiari G.M., L. Moretta. Cellular and molecular interactions of mesenchymal stem cells in innate immunity. Immunol Cell Biol 2013; 91(1): 27-31.

18. Tarasov A.I., Petrenko A.Yu., Grischenko V.I., Jones D.R.E. Postthaw viability of human fetal liver cells of different phenotype. Probl Cryobiol 2002; 3: 36-41. 